Georgia State University

ScholarWorks @ Georgia State University

$9-1-2018$

\title{
Fiscal Decentralization and Government Size: The Role of Democracy
}

Mo Qiao

Peking University

Siying Ding

Renmin University of China

Yongzheng Liu

Renmin University of China

Follow this and additional works at: https://scholarworks.gsu.edu/icepp

\section{Recommended Citation}

Qiao, Mo; Ding, Siying; and Liu, Yongzheng, "Fiscal Decentralization and Government Size: The Role of Democracy" (2018). ICEPP Working Papers. 157.

https://scholarworks.gsu.edu/icepp/157

This Article is brought to you for free and open access by the International Center for Public Policy at ScholarWorks @ Georgia State University. It has been accepted for inclusion in ICEPP Working Papers by an authorized administrator of ScholarWorks @ Georgia State University. For more information, please contact scholarworks@gsu.edu. 


\section{International Center for Public Policy}

International Center for Public Policy Working Paper 18-18 September 2018

Fiscal Decentralization and Government Size: The Role of Democracy

Mo Qiao

Siying Ding

Yongzheng Liu 


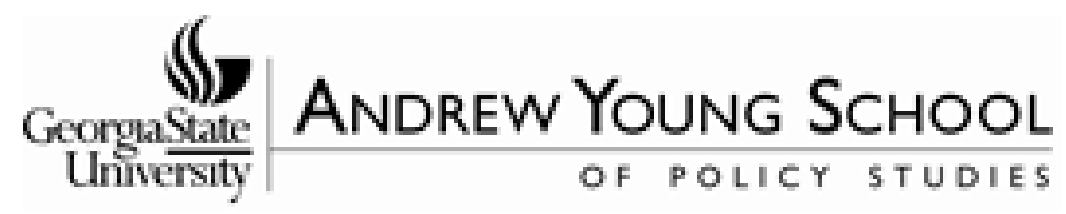

\section{International Center for Public Policy Working Paper 18-18}

\section{Fiscal Decentralization and Government Size: The Role of Democracy}

Mo Qiao

Siying Ding

Yongzheng Liu

\section{September 2018}

International Center for Public Policy

Andrew Young School of Policy Studies

Georgia State University

Atlanta, Georgia 30303

United States of America

Phone: (404) 413-0235

Fax: (404) 651-4449

Email: paulbenson@gsu.edu

Internet: http://icepp.gsu.edu/

Copyright 2018, the Andrew Young School of Policy Studies, Georgia State University. No part of the material protected by this copyright notice may be reproduced or utilized in any form or by any means without prior written permission from the copyright owner. 


\section{International Center for Public Policy Andrew Young School of Policy Studies}

The Andrew Young School of Policy Studies was established at Georgia State University with the objective of promoting excellence in the design, implementation, and evaluation of public policy. In addition to two academic departments (economics and public administration), the Andrew Young School houses seven leading research centers and policy programs, including the International Center for Public Policy.

The mission of the International Center for Public Policy is to provide academic and professional training, applied research, and technical assistance in support of sound public policy and sustainable economic growth in developing and transitional economies.

The International Center for Public Policy at the Andrew Young School of Policy Studies is recognized worldwide for its efforts in support of economic and public policy reforms through technical assistance and training around the world. This reputation has been built serving a diverse client base, including the World Bank, the U.S. Agency for International Development (USAID), the United Nations Development Programme (UNDP), finance ministries, government organizations, legislative bodies and private sector institutions.

The success of the International Center for Public Policy reflects the breadth and depth of the in-house technical expertise that the International Center for Public Policy can draw upon. The Andrew Young School's faculty are leading experts in economics and public policy and have authored books, published in major academic and technical journals, and have extensive experience in designing and implementing technical assistance and training programs. Andrew Young School faculty have been active in policy reform in over 40 countries around the world. Our technical assistance strategy is not to merely provide technical prescriptions for policy reform, but to engage in a collaborative effort with the host government and donor agency to identify and analyze the issues at hand, arrive at policy solutions and implement reforms.

The International Center for Public Policy specializes in four broad policy areas:

- Fiscal policy, including tax reforms, public expenditure reviews, tax administration reform

- Fiscal decentralization, including fiscal decentralization reforms, design of intergovernmental transfer systems, urban government finance

- Budgeting and fiscal management, including local government budgeting, performancebased budgeting, capital budgeting, multi-year budgeting

- Economic analysis and revenue forecasting, including micro-simulation, time series forecasting,

For more information about our technical assistance activities and training programs, please visit our website at https://icepp.gsu.edu or contact us by email at paulbenson@gsu.edu. 


\title{
Fiscal Decentralization and Government Size: The Role of Democracy*
}

\author{
Mo Qiao \\ Peking University \\ Siying Ding \\ Renmin University of China \\ $\&$ \\ Indiana University Bloomington \\ Yongzheng Liu \\ Renmin University of China
}

\begin{abstract}
This paper examines how the level of democracy in a country affects the relationship between fiscal decentralization and government size. We argue that political regimes, proxied by their democracy levels, are important for different decentralization theories to predict the impact of fiscal decentralization on government size. We test this argument using cross-country data from 76 developed and developing countries during 1972-2013. We find strong and robust evidence that fiscal decentralization is negatively associated with government size and that a higher level of democracy tends to mitigate the negative impact of fiscal decentralization. Therefore, our study contributes to the literature by offering a novel insight on mixed results regarding the relationship between fiscal decentralization and government size in the literature.
\end{abstract}

Keywords: Fiscal Decentralization; Government Size; Democracy; Cross-Country

JEL Classifications: D72; H11; H77

\footnotetext{
${ }^{*}$ This paper is supported by the Fundamental Research Funds for the Central Universities, and the Research Funds of Renmin University of China (18XNA003). Please address all correspondence to: Yongzheng Liu, School of Finance, Renmin University of China, Beijing, 100872 China (E-mail: yongzheng.liu@ruc.edu.cn; phone +86 10-82500501; fax +1 10-82509260).
} 


\section{Introduction}

During the past decades, numerous countries worldwide, both developed and developing countries, have undergone decentralization in terms of their fiscal, political, and administrative structures. The growing interest for this topic in academic research has triggered intense discussions on its various aspects, especially the consequences of fiscal decentralization. To date, the literature has identified a wide range of potential impacts of fiscal decentralization on a country, including economic growth, regional disparity, macroeconomic stability, corruption, and government size (see MartinezVazquez et al., 2017 for a survey). Among them, one of the most relevant and discussed consequences is the impact of fiscal decentralization on government size, for which limited consensus has been reached, both theoretically and empirically (Golem, 2010).

This paper re-examines empirically the effect of fiscal decentralization on government size by considering the role of a country's political regime (proxied by democracy). We contribute to the literature by offering a novel explanation on the mixed results regarding the relationship between fiscal decentralization and government size in the literature. Theoretically, fiscal decentralization, as explained in the subsequent section, has important implications on government size, although competing explanations exist. Specifically, by assuming the government as a benevolent agent that serves the needs of its constituents, the "first-generation" of fiscal federalism argues that, in the presence of heterogeneous preferences and needs across different jurisdictions, fiscal decentralization may increase the efficiency and quality of government services because it allows for a closer match between the preferences of residents and the packages of public goods and services provided by local governments (Tiebout, 1956; Oates, 1972; Weingast, 2009). Therefore, greater decentralization can be considered to enhance local accountability and residents' trust in government, which motivates them to demand more public goods and services, hence leading to a greater government size (Golem, 2010). By assuming the government as a monolithic Leviathan, with selfish public officials to maximize revenues, as opposed to the benevolent government assumed in the previous literature, the "second-generation" of fiscal federalism argues that, for attracting/maintaining mobile tax bases (i.e., residents 
and firms), tax competition among governments under the decentralized system destroys the Leviathan's monopoly on taxation and brings government spending closer to the preferences of residents, thus potentially leading to less bureaucratic waste of resources and a smaller size for government spending (Weingast, 2009; Golem, 2010).

Therefore, these different predictions for the relationship between fiscal decentralization and government size are based, at least partially, on the particular political regimes that give rise to different government types. We argue that, compared to non-democratic regimes, democratic regimes are more likely to support a benevolent government, meaning fiscal decentralization in democratic countries is more likely to improve local accountability, resulting in a relatively larger government size. We test this hypothesis using a cross-country dataset of 76 developed and developing countries for the period 1972-2013. We find strong evidence that (1) overall, fiscal decentralization is negatively associated with government size, supporting decentralization as a device to promote local competition thus restricting government size increases, and (2) fiscal decentralization in countries with a higher level of democracy tends to have a smaller negative impact on government size than countries with lower democracy levels. We thus contribute to the literature by providing an explanation that integrates the apparently conflicting views on the relationship between fiscal decentralization and government size. These results are robust across alternative measures of key variables and alternative specifications, data frames, and estimation approaches.

The rest of the paper is organized as follows. Section 2 reviews the related literature and discusses the potential role of democracy in the nexus between fiscal decentralization and government size. Section 3 proposes the empirical methodology and discusses the data. Section 4 presents the empirical results. Section 5 provides additional robustness checks. Finally, Section 6 concludes the paper. 


\section{$\underline{\text { 2. Literature Review }}$}

\subsection{Fiscal decentralization and government size}

The literature of fiscal federalism has long discussed the impact of fiscal decentralization on government size. Particularly, two different viewpoints dominate the literature, both empirically controversial. The first viewpoint originates from the traditional theory of fiscal federalism, the so-called "first-generation" of fiscal federalism, which draws heavily from the seminal work of Tiebout (1956), Musgrave (1959), and Oates (1972), among others. In this literature stream, governments are assumed to act benevolently in the interest of residents, who are in turn assumed to be able to move freely to jurisdictions best suiting their preferences. Therefore, the devolution of tax and expenditure authority under a decentralized system improves the efficiency of public goods provision because decentralization leads to information advantages and, in the presence of heterogeneous preferences, allows local governments to response more flexibly to the needs and preferences of their residents. The resulting increases in local accountability and residents' trust in the government further motivate residents to demand more public goods and services, hence leading to an expansion in government size. In other words, with the presumption of government benevolence and resident mobility, government size is determined by the demand for government expenditure, while decentralization helps stimulate demand.

Apart from the demand-side explanation of the impact of fiscal decentralization on government size, the development of fiscal federalism literature, the so-called "second-generation" of fiscal federalism, introduces a supply-side explanation, which results in an opposite prediction of the impact of fiscal decentralization on government size. Specifically, by abandoning the assumption of a benevolent government, this literature stream assumes the government to be selfish, depicted as a monolithic Leviathan that seeks to maximize revenues and expand its scale through excessive taxation, deficit, and money generation (Weingast, 2009; Golem, 2010). Therefore, a centralized system, compared to a decentralized one, makes the government easier to conceal and follow its selfish interests, while leaving less constraining power to 
taxpayers or citizens to control such a large government. In this case, the decentralization of taxation and spending power is argued to be a potentially effective way to constrain an unreasonable expansion of the government because decentralization may trigger an inter-jurisdictional competition for mobile tax bases (i.e., firms and residents), meaning any attempt by a local jurisdiction to abuse taxation and/or spending will result in the relocation of its tax bases to an alternative jurisdiction. Owing to this competitive pressure, each local jurisdiction tends to reduce its tax burden, which consequently affects the supply of local public goods and services. In an extreme case, the fierce tax competition under a decentralized economy may even result in the so-called "race to the bottom" phenomenon, characterized by an inefficiently low tax rate and, hence, a reduced government size (Zodrow and Mieszkowski, 1986; Wilson, 1986, 1999; Wilson and Wildasin, 2004).

Empirically, numerous studies investigate the relationship between fiscal decentralization and government size using different datasets, time frames, and econometric methods, but no consensus seems to have been hitherto reached. In an early stage, Oates (1985), Nelson (1986), Marlow (1988), and Forbes and Zampelli (1989) made pioneering contributions to this research area. Oates (1985) uses a sample of 48 US contiguous states and 43 developed and developing countries and fails to find a significant Leviathan effect. By using US state and county data, respectively, Nelson (1986) and Forbes and Zampelli (1989) do not find significant results in support of the Leviathan hypothesis either. Nevertheless, Marlow (1988) identifies a negative and significant impact of expenditure decentralization, measured by the ratio of state and local government spending to total government spending, on government size by using US national-level data for the period 1946-1985. Grossman (1989) reports the same finding as those of Marlow (1988) and further emphasizes that intergovernmental grants increase government size due to the moral hazard behaviors of local governments.

Recent research showed increasing attention to cross-country datasets. For instance, Ehdaie (1994) uses two cross-country datasets for two different years and finds an insignificant effect of fiscal decentralization on government size. Stein (1999) 
explores a Latin American country dataset with a special focus on intergovernmental transfers and finds vertical fiscal imbalance and borrowing autonomy tend to increase government size. Jin and Zou (2002) provide a more detailed classification of different government levels, and find that fiscal decentralization reduces the size of the national government but increases the sizes of sub-national governments, overall increasing the size of governments. Rodden (2003) investigates a panel dataset covering 19 OECD countries from 1985 to 1995, and suggests that a smaller government size corresponds to a decentralized system where local governments are primarily financed by local tax revenues instead of intergovernmental grants. Based on a large cross-country dataset and using the total number of public-sector employees as a measure of government size, Martinez-Vazquez and Yao (2009) find that, ceteris paribus, a country's government size increases with its level of fiscal decentralization. Particularly, while fiscal decentralization decreases central government employment, it is more than fully offset by the increases in employment at the subnational level that accompany decentralization.

\subsection{Why does democracy matter?}

As previously discussed, the nexus between fiscal decentralization and government size is neither theoretically definitive nor empirically clear. We argue an increased focus needs to be placed on the relevance of political regimes, since they have strong implications for the functioning of different theories and thus condition the relationship between fiscal decentralization and government size. Particularly, the traditional theory of fiscal federalism, which predicts a larger government size in decentralized economies assumes: (i) the presence of a benevolent government that is responsive and accountable for the preferences and needs of local residents and (ii) the mobility of residents reinforcing inter-jurisdictional competition and enhancing local accountability, since residents can vote "with their feet" and arrange themselves into homogeneous communities, where their preferences are maximized. Under these assumptions, it seems unlikely the aforementioned prediction of the traditional theory of fiscal federalism will hold if no democratic institutions exist. Specifically, given a 
mature democracy, the various monitoring mechanisms, such as elections and press freedom, may function well, which is essential to guarantee the existence of a benevolent government that acts in the interest of residents (Karlström, 2015). Further, to ensure inter-jurisdictional competition as an effective mechanism to improve local accountability, there must be institutions supporting the free mobility of residents across jurisdictions, so that residents are able to vote with their feet, and free information should flow to residents and firms, so that they can compare policy outcomes and government quality in their home jurisdiction with those of other jurisdictions. Unfortunately, these freedoms are typically restricted in many nondemocratic or authoritarian countries (Beyani, 2000). Consequently, the prediction of the traditional theory of fiscal federalism for a larger government size is more likely to occur in countries with democratic institutions. We thus hypothesize that the level of democracy may condition the relationship between decentralization and government size. As such, by exploring the role of democracy, we also offer another explanation for the inconsistent results in the empirical literature on the relationship between fiscal decentralization and government size.

\section{Empirical Strategy and Data}

\subsection{Econometric specification}

We investigate the effect of fiscal decentralization on government size, with a particular focus on the role of democracy. To achieve this purpose, we estimate the following fixed effects model:

Govsize $_{i t}=\alpha+\beta F D_{i, t-1}+\theta$ Demo $_{i, t-1}+\delta F D_{i, t-1} \times$ Demo $_{i, t-1}+\gamma X_{i, t-1}+\mu_{i}+$ $\varphi_{t}+\varepsilon_{i t}$,

where the dependent variable (i.e., Govsize $i t$ ) represents the government size of country $i$ in year $t . F D_{i, t-1}$ is the fiscal decentralization indicator of the country and is lagged by one period to avoid the potential endogeneity issue. Demo $o_{i, t-1}$ is a lagged democracy index. $F D_{i, t-1} \times D e m o_{i, t-1}$ is the interaction term between the two variables, being a key variable. Based on the previous theoretical illustration, we expect 
to find a positive sign for coefficient $\delta$, implying that with the increase in the democratic level of a country, fiscal decentralization is more likely to result in a larger government size. $\mu_{i}$ is the time-invariant and country-specific effect of country $i ; \varphi_{t}$ is a set of year dummies, and $\varepsilon_{i t}$ is the i.i.d. error term.

Regarding the control variable $X_{i, t-1}$, we seek to capture the general determinants of government size based on the empirical literature. These include real GDP per capita, share of the secondary sector in total GDP, trade openness, urbanization rate, and demographic variables. Real GDP per capita (in log form) and the share of the secondary sector in total GDP stand for the economic development level of the country. It has long been argued that economic development generally leads to a simultaneous increase in the demand for more and better public services (e.g., Wagner, 1893; Akitoby et al., 2006; Wu and Lin, 2012). Trade openness is typically believed to lead to a larger government size, as voters seek insurance against external shocks when the country is exposed to international trade (Cameron, 1978; Rodrik, 1998). However, a competing view is that openness restrains government size by imposing balance of payments constraints, thus reducing the power of domestic special interests (Ferris et al., 2008). As such, we include trade openness, measured as the ratio of total trade (exports and imports) to GDP, to control for this effect. Additionally, the urbanization rate can be presumed to determine government consumption and investment (Alesina and Wacziarg, 1998), and we capture this effect by measuring it as the share of urban population to total population. Finally, the relative size of the nonworking population may matter for the level of public expenditure because a younger population demands more education services, while the elderly require more health care. Therefore, we might hypothesize that governments will be larger in countries where the non-working population represents a greater percentage of the total population. We thus follow Rodden (2003) and others in capturing this factor through two variables - the proportion of individuals aged 0-14 and of those aged 65 and above. All control variables are lagged by one period to avoid any bias due to the concern of reverse causality. 


\subsection{Data}

The panel dataset we used covers 76 developed and developing countries during 19722013. ${ }^{2}$ The variables are derived from a wide range of sources. Our measure of government size, as the ratio of total general government expenditure to the GDP, is obtained from the World Development Indicators database. This measure of government size is a traditional one in the literature (see, for example, Stein, 1999; Jin and Zou, 2002; Rodden, 2003; Kotera et al., 2012).

Measuring the extent of fiscal decentralization has been long debated in both theoretical and empirical studies largely because fiscal decentralization happens along several dimensions and at different paces. Therefore, no single indicator can adequately capture the full picture of this process, which would ideally be measured separately for each dimension (Martinez-Vazquez and McNab, 2003; Stegarescu, 2005). Nevertheless, this issue can be at least partially overcome by considering alternative indicators that reflect the different aspects of the decentralization process (Liu et al., 2017). Consequently, we measure a country's fiscal decentralization by simultaneously considering both expenditure and revenue. Of these two indicators, expenditure decentralization, defined as the ratio of state and local government spending to total general government spending, has been most widely used in the literature (e.g., Oates, 1985; Davoodi and Zou, 1998; de Mello, 2000), as it captures the degree of local governments' expenditure responsibilities in the public sector, that is, it quantifies who does what. Therefore, we rely on expenditure decentralization as our primary measure of fiscal decentralization and utilize revenue decentralization as an alternative measure of fiscal decentralization to verify the robustness of our results. The data for both measures of fiscal decentralization are obtained from the World Bank's Decentralization Indicator database, which calculates the indexes based on raw data from the Government Finance Statistics of the International Monetary Fund.

\footnotetext{
${ }^{2}$ The list of countries in our sample is provided in Table A1 in the Appendix.
} 
Democracy, another key variable of interest, is a relative concept that reflects the degree of civil liberties and political rights across countries. We construct it by using the average of political rights and civil liberties provided by the Freedom House. ${ }^{3}$ However, it is rescaled to take values from 0 to 10 , with larger values signifying a more democratic regime. All other economic variables are derived from the World Development Indicator database. Variable definitions are presented in Table A2 in the Appendix and summary statistics are reported in Table 1.

\section{Main Empirical Results}

Table 2 presents the estimation results for baseline model (1), where fiscal decentralization is measured through its expenditure. All specifications are estimated using a fixed effects model.

To begin with, we examine the net effect of fiscal decentralization on government size without considering the role of democracy. Columns (1) and (2) respectively report the results controlling or not for year fixed effects in the estimations. The coefficient of expenditure decentralization is negative and statistically significant at the $1 \%$ level in both columns, suggesting an increase of fiscal decentralization leads to a smaller government size. This finding lends support to the prediction of the "secondgeneration" of fiscal federalism, which presumes the existence of a Leviathan-type government, meaning decentralization tends to restrict the growth in government spending by encouraging an inter-jurisdictional tax competition. Quantitatively, taking Column (2) as reference, the estimated net effect of the expenditure decentralization is -0.069 , implying a one percentage point increase in expenditure decentralization reduces government size (i.e., total government expenditure as a percent of GDP) by 0.069 percentage points.

\footnotetext{
${ }^{3}$ In the Freedom House index, both "political rights" and "civil liberties" range from 1 (most free) to 7 (least free). The indicators for political rights include an effective election system of public institutions, political party pluralism, fair elections and voting rights, and the decentralization of political power. The indicators of civil liberties include the public freedom of expression, freedom of assembly and demonstration, doing trade, as well as social and economic rights of the individual.
} 
However, the estimates in Columns (1) and (2) may not be precise. This is because, as illustrated in Section 2, the impact of fiscal decentralization on government size may depend on the political regime in which the decentralization system operates. Particularly, the level of democracy in a country may act as a significant and direct determinant of the impact of fiscal decentralization on government size. Thus, we consider the interaction effect between fiscal decentralization and democracy. This interaction term allows us to evaluate how the democracy level in a country influences the effect of fiscal decentralization on government size. Columns (3) and (4) provide the results for when the interaction term between fiscal decentralization and democracy is added. As predicted, the estimated coefficient of the interaction term is significantly positive, implying the negative effect of fiscal decentralization on government size is diminishing with the increase of a country's democracy level. This result is largely consistent with our previous theoretical demonstration that democracy may condition the relationship between fiscal decentralization and government size, particularly the prediction of the traditional theory of fiscal federalism that a larger government size is more likely in countries with democratic institutions.

While the results above are informative, they remain somewhat limited as they do not directly indicate the net partial impact of fiscal decentralization on government size or whether fiscal decentralization has a statistically significant impact on government size when the democracy level of a country does not equal $0 .{ }^{4}$ Therefore, based on Column (4) of Table 2, we illustrate in Figure 1 the marginal effect of fiscal decentralization on government size across the observed range of democracy levels. The solid sloping line indicates how the marginal effect of fiscal decentralization changes as the level of democracy of a country increases, while the two dashed lines, representing $95 \%$ confidence intervals, allow us to determine the conditions under which fiscal decentralization has a statistically significant effect on government size-

\footnotetext{
${ }^{4}$ In specifications with interaction terms, the statistical significance of an individual variable does not necessarily imply its marginal effect is statistically significant (see Brambor et al., 2006).
} 
the net effect of fiscal decentralization is significant whenever the upper and lower bounds of the confidence interval are both below 0. As per Figure 1, the partial effect of fiscal decentralization is strictly negative and statistically significant through the entire range of democracy. Nevertheless, the increase in the democracy level clearly indicates the negative effect of fiscal equalization is diminishing.

Regarding the other control variables, the results are mostly consistent with our prediction. Real GDP per capita has positive and significant coefficients, supporting Wagner's law in that economic development leads to a larger demand of public goods and services. Trade openness contributes to a smaller government size, indicating openness may restraint government size by imposing balance of payments constraints. The proportion of the younger population is positively associated with government size, reflecting the special needs of government services from this group. The estimates for other control variables are generally statistically insignificant.

\section{Robustness Checks}

To test the robustness of the main results, we conduct sensitivity analyses along three dimensions: using alternative measures of the key variables, that is, fiscal decentralization, government size, and democracy; using an alternative data structure; and using an alternative specification addressing the endogeneity concern of fiscal decentralization. In all robustness checks, we find results from the specifications equivalent to those in Columns (3) and (4) of Table 2.

\subsection{Alternative measures of key variables}

We first use alternative measures for the key variables. Instead of measuring decentralization from the expenditure side, we consider its revenue side, which may reflect different aspects of the fiscal decentralization process. Specifically, we measure revenue decentralization as the ratio of state and local government revenue to total general government revenue and re-estimate specification (1). The estimated results are reported in Columns (1) and (2) of Table 3. The estimated coefficient of revenue decentralization remains negative and statistically significant and its interaction term 
with democracy remains significantly positive. Moreover, the quantitative effects of revenue decentralization are also similar to those of expenditure decentralization in Columns (3) and (4) of Table 2. Second, we conduct the estimations using another proxy for government size - total employment in the public sector (in log form) — which is another popular measure of government size in the literature (see, for example, Martinez-Vazquez and Yao, 2009). The estimated results are shown in Columns (3) and (4) of Table 3, with expenditure decentralization being negatively and significantly associated with the new measure of government size. The interaction term between expenditure decentralization and democracy is positive and statistically significant at the margin in Column (3) of Table 3. However, it is also statistically significant in Column (4) of Table 3, when year fixed effects are controlled for.

Further, we use an alternative democracy index to perform robustness checks. That is, the index of political democracy and autocracy derived from the Polity IV Project dataset, which ranges from -10 (strongly autocratic) to +10 (strongly democratic). The variable is a combination of three independent elements of institutionalized democracy: (i) presence of institutions and procedures through which citizens can express effective preferences about alternative politicians and leaders, (ii) existence of institutionalized constraints on the exercise of power by the executive, and (iii) guarantee of civil liberties to all citizens in their daily life and for acts of political participation. Because of its comprehensiveness in measuring democracy, this variable has also been frequently used in the literature (e.g., Swamy et al., 2001; Gatti, 2004). Therefore, we use it as an alternative democracy measure and re-estimate the model. The estimated results are documented in Columns (5) and (6) of Table 3, according to which expenditure decentralization has a negative impact on government size, while the democracy level of a country tends to mitigate this negative impact.

\subsection{Alternative data structure}

To further verify the robustness of the results, we alternatively explore a different data structure. Particularly, since we may not expect a year-on-year change between fiscal 
decentralization and government size because the latter variable is likely to be affected by short-run business cycles and the level of democracy in a country is generally stable for long periods of time, focusing on the average values of our variables may help reduce the short-run fluctuations and allow us to examine the long-run relationship between fiscal decentralization and government size and how it varies across different democracy levels. Consequently, we re-estimate specification (1) by transforming yearly data into 5-year intervals (i.e., 1972-1974, 1975-1979, ..., 2005-2009, 20102013) and 10-year intervals (i.e., 1972-1979, 1980-1989, 1990-1999, 2000-2009, 2010-2013). The results are reported in Table 4 and are largely unchanged compared to the baseline results in Table 2, with only the estimated coefficient of the interaction term being quantitatively larger. Therefore, our baseline results seem not to be affected by the short-run business cycle and the potential measurement errors.

\subsection{Addressing the endogeneity concern}

An important concern in estimating specification (1) is that of potential endogeneity for a country's fiscal decentralization. Theoretically, this issue may arise because of reverse causality, omitted variable bias, or measurement errors. Although we have tried to mitigate this issue to a large extent in the previous estimations, namely taking oneperiod lags of all explanatory variables and utilizing alternative measures of key variables and data frames, the endogeneity issue may still be of concern. Previous studies on the impacts of fiscal decentralization have also acknowledged the potential endogeneity bias in their estimates, although they do not explicitly control for it, ${ }^{5}$ to a large extent due to small sample sizes and lack of adequate instruments (e.g., Zhang and Zou, 1998; Jin et al., 2005; Qiao et al., 2008). Here, we account for the potential endogeneity issue of fiscal decentralization more explicitly by using an instrumental variable approach. The instruments we use include one- and two-period lagged values of the weighted average of fiscal decentralization from neighboring countries (weighed

\footnotetext{
${ }^{5}$ Fisman and Gatti (2002) and Iimi (2005) are the two exceptions in the literature.
} 
by the contiguity matrix ${ }^{6}$ ). The validity of this instrument is justified by the design of fiscal decentralization policy in a country being possibly correlated with the design of decentralization policies in neighboring countries because of their geographical similarity and potential competitive and mimicking behaviors, while the government size of a country should have virtually no direct impact on the design of the fiscal decentralization of neighboring countries in the preceding years.

Table 5 documents the results of the instrumental variable method, where fiscal decentralization is treated as an endogenous variable. For all specifications, the Fstatistics are close to or above 10, which suggests the relevancy of our instruments is indeed strong. Additionally, the Hansen J Statistic of over-identification restriction in Table 5 is in almost all cases above 0.10 , implying we cannot reject the null hypothesis of no correlation between the instruments and error term in the regressions.

Comparing the results in Tables 5 and 2 confirms our earlier findings: fiscal decentralization leads to a smaller government size, while the democracy level of a country helps reduce the negative effect of fiscal decentralization on government size. Further, the parameter estimates in Table 5 are quantitatively larger than those in Table 2, potentially suggesting the endogeneity issue may lead to under-estimated effects of fiscal decentralization and democracy in the baseline estimations.

\section{Concluding Remarks}

The impact of fiscal decentralization on government size has been discussed in great depth in the literature, but limited consensus has been reached either theoretically or empirically. To explain the mixed results in the literature, we investigate the extent to which the level of democracy determines the effect of fiscal decentralization on government size. We hypothesize fiscal decentralization is more likely to result in a larger government size in a country with a higher democracy level, where a benevolent government is more likely to exist and local officers are more likely to be accountable

\footnotetext{
${ }^{6}$ That is, a value of 1 is assigned if two countries share the same border, and 0 otherwise. The underlying assumption is that geographically closer countries interact more strongly in policy settings.
} 
for the needs of local residents. By contrast, fiscal decentralization is more likely to result in a smaller government size in a country with a lower democracy level, where a Leviathan-type government is more likely to exist and decentralization tends to restrain government size by fostering inter-jurisdictional competition.

We then confront this theoretical prediction with the results from a crosscountry dataset covering 76 developed and developing countries over 1972-2013. We find supporting evidence that an increase in the fiscal decentralization of a country reduces the government size and the negative impact of fiscal decentralization tends to be weakened in countries with higher democracy levels. These results are robust across alternative measures of key variables, alternative data frames, and specifications correcting for the endogeneity of fiscal decentralization.

The results are both academically and policy-wise relevant. Academically, they contribute to a better understanding of the nexus between fiscal decentralization and government size in the literature. By focusing on the role of democracy, we highlight the specific conditions for the potential conflicting predictions of different decentralization theories. Consequently, by introducing the determining effect of the democracy level, our study thus potentially explains the mixed results in the empirical literature on the relationship between fiscal decentralization and government size. From the policy perspective, fiscal decentralization has been advocated by many organizations, such as the World Bank, for different reasons. Our results suggest that fiscal decentralization may be used to address the inefficient expansion of government size in countries without democratic institutions, where decentralization encourages inter-jurisdictional competition for mobile tax bases, thus restraining the inefficient use of government resources. 


\section{References}

Akitoby, B., Clements, B., Gupta, S., \& Inchauste, G. (2006). Public spending, voracity, and Wagner's law in developing countries. European Journal of Political Economy, 22(4), 908-924.

Alesina, A., \& Wacziarg, R. (1998). Openness, country size and government. Journal of Public Economics, 69(3), 305-321.

Beyani, C. (2000). Human rights standards and the free movement of people within states. Oxford: Oxford University Press.

Brambor, T., Clark, W. R., \& Golder, M. (2006). Understanding interaction models: Improving empirical analyses. Political Analysis, 14(1), 63-85.

Cameron, D. (1978). The expansion of the public economy: A comparative analysis. American Political Science Review, 72(4), 1243-1261.

Davoodi, H., \& Zou, H.-f. (1998). Fiscal decentralization and economic growth: A cross-country study. Journal of Urban Economics, 43(2), 244-257.

de Mello, L. R. (2000). Fiscal decentralization and intergovernmental fiscal relations: A cross-country analysis. World Development, 28(2), 365-380.

Ehdaie, J. (1994). Fiscal decentralization and the size of government: An extension with evidence from cross-county data. World Bank Policy Research Working Paper Series, No.1387.

Ferris, J. S., Park, S.-B., \& Winer, S. L. (2008). Studying the role of political competition in the evolution of government size over long horizons. Public Choice, 137(1), 369-401.

Fisman, R., \& Gatti, R. (2002). Decentralization and corruption: Evidence across countries. Journal of Public Economics, 83(3), 325-345.

Forbes, K. F., \& Zampelli, E. M. (1989). Is Leviathan a mythical beast? American Economic Review, 79(3), 568-577.

Gatti, R. (2004). Explaining corruption: Are open countries less corrupt? Journal of International Development, 16(6), 851-861.

Golem, S. (2010). Fiscal decentralisation and the size of government: A review of the empirical literature. Financial Theory and Practice, 34(1), 53-69.

Grossman, P. J. (1989). Fiscal decentralization and government size: An extension. Public Choice, 62(1), 63-69.

Iimi, A. (2005). Decentralization and economic growth revisited: An empirical note. Journal of Urban Economics, 57(3), 449-461.

Jin, H., Qian, Y., \& Weingast, B. R. (2005). Regional decentralization and fiscal incentives: Federalism, Chinese style. Journal of Public Economics, 89(9), 1719-1742.

Jin, J., \& Zou, H.-f. (2002). How does fiscal decentralization affect aggregate, national, and subnational government size? Journal of Urban Economics, 52(2), 270-293.

Karlström, K. (2015). Decentralization, corruption, and the role of democracy. $Q o G$ Working Paper Series 2015:14. 
Kotera, G., Okada, K., \& Samreth, S. (2012). Government size, democracy, and corruption: An empirical investigation. Economic Modelling, 29(6), 23402348.

Liu, Y., Martinez-Vazquez, J., \& Wu, A. M. (2017). Fiscal decentralization, equalization, and intra-provincial inequality in China. International Tax and Public Finance, 24(2), 248-281.

Marlow, M. L. (1988). Fiscal decentralization and government size. Public Choice, 56(3), 259-269.

Martinez-Vazquez, J., Lago-Peñas, S., \& Sacchi, A. (2017). The impact of fiscal decentralization: A survey. Journal of Economic Surveys, 31(4), 1095-1129.

Martinez-Vazquez, J., \& McNab, R. M. (2003). Fiscal decentralization and economic growth. World Development, 31(9), 1597-1616.

Martinez-Vazquez, J., \& Yao, M.-H. (2009). Fiscal decentralization and public sector employment: A cross-country analysis. Public Finance Review, 37(5), 539571.

Musgrave, R. A. (1959). The Theory of Public Finance. New York: McGraw Hill.

Nelson, M. A. (1986). An empirical analysis of state and local tax structure in the context of the Leviathan model of government. Public Choice, 49(3), 283-294.

Oates, W. E. (1972). Fiscal Federalism. New York: Harcourt Brace Jovanovich.

Oates, W. E. (1985). Searching for Leviathan: An Empirical Study. The American Economic Review, 75(4), 748-757.

Qiao, B., Martinez-Vazquez, J., \& Xu, Y. (2008). The tradeoff between growth and equity in decentralization policy: China's experience. Journal of Development Economics, 86(1), 112-128.

Rodden, J. (2003). Reviving Leviathan: Fiscal federalism and the growth of government. International Organization, 57(4), 695-729.

Rodrik, D. (1998). Why do more open economies have bigger governments? Journal of Political Economy, 106(5), 997-1032.

Stegarescu, D. (2005). Public sector decentralisation: Measurement concepts and recent international trends. Fiscal Studies, 26(3), 301-333.

Stein, E. (1999). Fiscal decentralization and government size in Latin America. Journal of Applied Economics, 2, 357-391.

Swamy, A., Knack, S., Lee, Y., \& Azfar, O. (2001). Gender and corruption. Journal of Development Economics, 64(1), 25-55.

Tiebout, C. M. (1956). A pure theory of local expenditures. Journal of Political Economy, 64(5), 416-424.

Wagner, A. (1893). Grundlegung der Politischen Oekonomie. Leipzig: C.F. Wintersche.

Weingast, B. R. (2009). Second generation fiscal federalism: The implications of fiscal incentives. Journal of Urban Economics, 65(3), 279-293.

Wilson, J. D. (1986). A theory of interregional tax competition. Journal of Urban Economics, 19(3), 296-315.

Wilson, J. D. (1999). Theories of Tax Competition. National Tax Journal, 52(2), 269304. 
Wilson, J. D., \& Wildasin, D. E. (2004). Capital tax competition: Bane or boon. Journal of Public Economics, 88(6), 1065-1091.

Wu, A. M., \& Lin, M. (2012). Determinants of government size: Evidence from China. Public Choice, 151(1-2), 255-270.

Zhang, T., \& Zou, H.-f. (1998). Fiscal decentralization, public spending, and economic growth in China. Journal of Public Economics, 67(2), 221-240.

Zodrow, G. R., \& Mieszkowski, P. (1986). Pigou, Tiebout, property taxation, and the underprovision of local public goods. Journal of Urban Economics, 19(3), 356-370. 


\section{Figure 1. Marginal Effect of Fiscal Decentralization on Government Size}

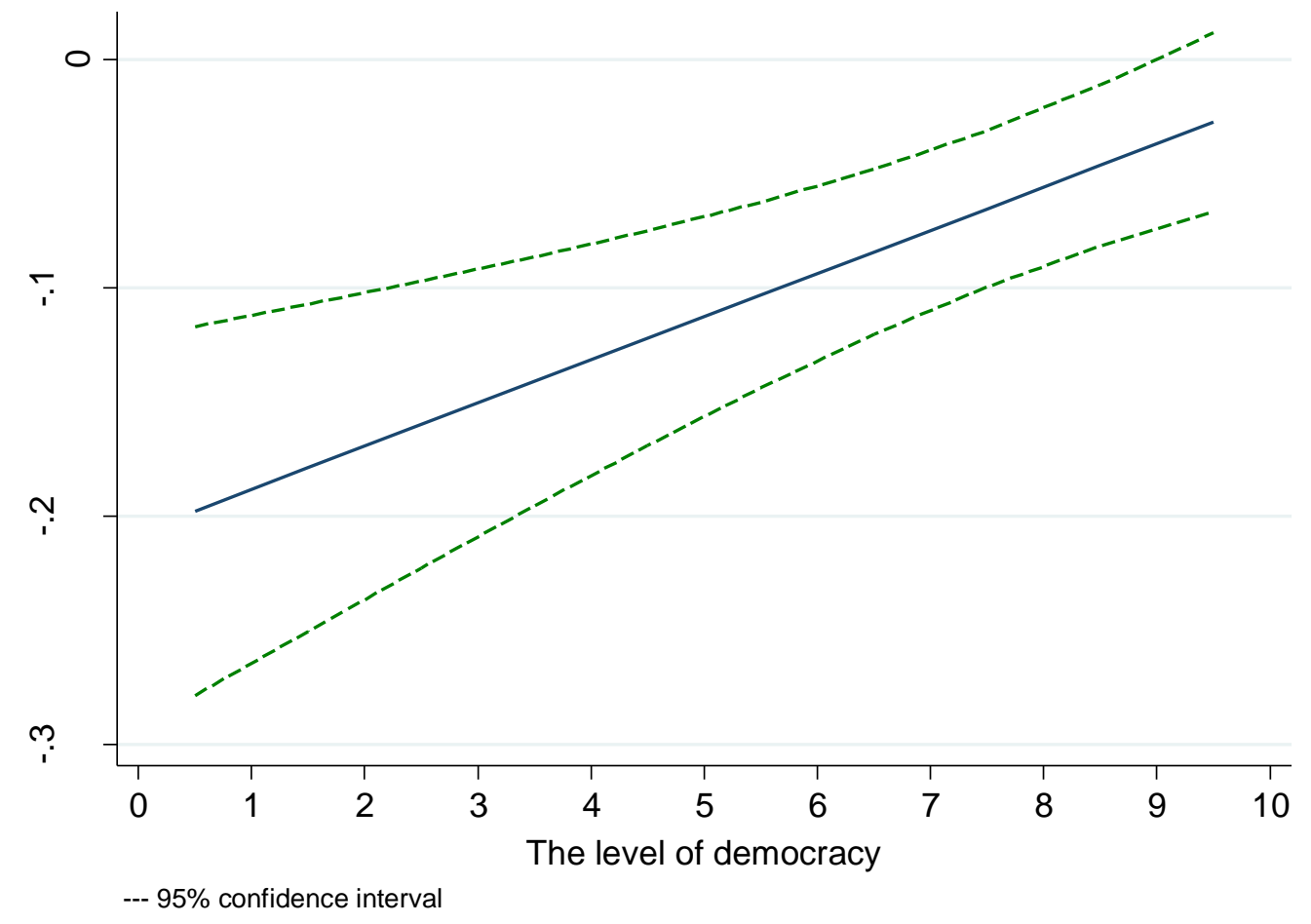

Note: this figure is illustrated based on the results of Column (4) in Table 2. Solid lines represent the estimated marginal effect of fiscal decentralization on government size. Dashed lines represent confidence interval based on 95\% confidence level for individual coefficients. 
Table 1. Summary Statistics

\begin{tabular}{llllll}
\hline Variable & Obs. & Mean & Std. Dev & Min & Max \\
\hline Government size, primary & 1,484 & 29.14 & 12.17 & 1.88 & 97.80 \\
Government size, alternative & 679 & 6.57 & 1.52 & 3.40 & 10.55 \\
Expenditure decentralization & 1,615 & 25.31 & 17.91 & 0.02 & 98.76 \\
Revenue decentralization & 1,643 & 26.73 & 16.06 & 0.43 & 98.76 \\
Democracy 1 & 1,660 & 8.14 & 2.67 & 0.50 & 10.00 \\
Democracy 2 & 1,630 & 6.73 & 5.49 & -10.00 & 10.00 \\
GDP per capita (log) & 1,660 & 9.32 & 1.35 & 5.43 & 11.63 \\
Secondary industry (\%) & 1,372 & 31.39 & 7.49 & 12.47 & 72.15 \\
Openness (\%) & 1,656 & 76.32 & 44.58 & 4.92 & 343.56 \\
Urbanization (\%) & 1,695 & 66.08 & 18.57 & 9.17 & 97.69 \\
Young population (\%) & 1,695 & 24.40 & 8.74 & 13.23 & 49.86 \\
Elderly population (\%) & 1,695 & 10.98 & 4.76 & 2.21 & 23.16 \\
IV: Weighted expenditure decentralization & 1,294 & 28.09 & 13.97 & 0.56 & 98.04 \\
\hline
\end{tabular}

Note: Authors' calculations. 
Table 2. Main Empirical Results

\begin{tabular}{lcccc}
\hline & $(1)$ & $(2)$ & $(3)$ & $(4)$ \\
\hline Expenditure decentralization, $t-1$ & $-0.065^{* * *}$ & $-0.069^{* * *}$ & $-0.193^{* * *}$ & $-0.207^{* * *}$ \\
Expenditure decentralization & $(0.017)$ & $(0.017)$ & $(0.041)$ & $(0.044)$ \\
*Democracy $1, t-1$ & & & $0.018^{* * *}$ & $0.019^{* * *}$ \\
Democracy 1, $t-1$ & & & $(0.005)$ & $(0.005)$ \\
& & & $-0.639^{* * *}$ & $-0.631^{* * *}$ \\
GDP per capita, $t-1$ & & $(0.169)$ & $(0.171)$ \\
& $6.212^{* * *}$ & $2.937 * *$ & $7.142^{* * *}$ & $4.072^{* * *}$ \\
Secondary industry, $t-1$ & $(1.042)$ & $(1.319)$ & $(1.060)$ & $(1.337)$ \\
& $-0.095^{* *}$ & -0.021 & $-0.162^{* * *}$ & $-0.089^{*}$ \\
Openness, $t-1$ & $(0.045)$ & $(0.049)$ & $(0.048)$ & $(0.052)$ \\
& $-0.058^{* * *}$ & $-0.069 * * *$ & $-0.060^{* * *}$ & $-0.070^{* * *}$ \\
Urbanization, $t-1$ & $(0.012)$ & $(0.012)$ & $(0.011)$ & $(0.012)$ \\
& 0.059 & -0.110 & 0.066 & -0.117 \\
Young population, $t-1$ & $(0.067)$ & $(0.079)$ & $(0.067)$ & $(0.079)$ \\
& 0.155 & $0.232^{* *}$ & $0.218^{* *}$ & $0.316^{* * *}$ \\
Elderly population, $t-1$ & $(0.100)$ & $(0.103)$ & $(0.107)$ & $(0.113)$ \\
& -0.025 & -0.241 & -0.070 & -0.274 \\
Country Fixed Effect & $(0.232)$ & $(0.239)$ & $(0.231)$ & $(0.238)$ \\
Year Fixed Effect & & & & \\
Observations & Yes & Yes & Yes & Yes \\
R-squared & No & Yes & No & Yes \\
\hline
\end{tabular}

Note: The dependent variable is the primary measure of government size. Standard error in parentheses; $* * * \mathrm{p}<0.01, * * \mathrm{p}<0.05, * \mathrm{p}<0.1$. 
Table 3. Robustness Checks: Alternative Measurement of Key Variables

\begin{tabular}{|c|c|c|c|c|c|c|}
\hline & \multicolumn{2}{|c|}{$\begin{array}{c}\text { Revenue } \\
\text { decentralization }\end{array}$} & \multicolumn{2}{|c|}{$\begin{array}{c}\text { Government size, } \\
\text { alternative }\end{array}$} & \multicolumn{2}{|c|}{ Democracy 2} \\
\hline & (1) & (2) & (3) & (4) & (5) & (6) \\
\hline $\begin{array}{l}\text { Revenue } \\
\text { decentralization, } t-1\end{array}$ & $\begin{array}{c}- \\
0.182 * * * \\
(0.039)\end{array}$ & $\begin{array}{c}- \\
0.211^{* * *} \\
(0.041)\end{array}$ & & & & \\
\hline $\begin{array}{l}\text { Revenue decentralization } \\
\text { *Democracy } 1, t-1\end{array}$ & $\begin{array}{c}0.022 * * * \\
(0.005)\end{array}$ & $\begin{array}{c}0.025 * * * \\
(0.005)\end{array}$ & & & & \\
\hline Expenditure decentralizatic & $\mathrm{n}, t-1$ & & $\begin{array}{l}-0.005^{*} \\
(0.003)\end{array}$ & $\begin{array}{c}-0.007 * * \\
(0.003)\end{array}$ & $\begin{array}{c}-0.096 * * * \\
(0.018)\end{array}$ & $\begin{array}{c}- \\
0.095 * * * \\
(0.018)\end{array}$ \\
\hline $\begin{array}{l}\text { Expenditure } \\
\text { decentralization } \\
\text { *Democracy } 1, t-1\end{array}$ & - & - & $\begin{array}{c}0.000 \\
(0.000)\end{array}$ & $\begin{array}{c}0.001 * * \\
(0.000)\end{array}$ & & \\
\hline Democracy $1, t-1$ & $\begin{array}{c}0.778 * * * \\
(0.172)\end{array}$ & $\begin{array}{c}0.792 * * * \\
(0.176)\end{array}$ & $\begin{array}{l}-0.005 \\
(0.014)\end{array}$ & $\begin{array}{l}-0.021 \\
(0.014)\end{array}$ & & \\
\hline $\begin{array}{l}\text { Expenditure } \\
\text { decentralization } \\
\quad \text { *Democracy 2, } t-1\end{array}$ & & & & & $\begin{array}{c}0.007 * * * \\
(0.002)\end{array}$ & $\begin{array}{c}0.007 * * * * \\
(0.002) \\
-\end{array}$ \\
\hline Democracy $2, t-1$ & & & & & $\begin{array}{c}-0.410 * * * \\
(0.062)\end{array}$ & $\begin{array}{c}0.430 * * * \\
(0.062)\end{array}$ \\
\hline GDP per capita, $t-1$ & $\begin{array}{c}7.161 * * * \\
(1.031)\end{array}$ & $\begin{array}{l}4.418 * * * \\
(1.286)\end{array}$ & $\begin{array}{c}0.115^{* *} \\
(0.058)\end{array}$ & $\begin{array}{l}-0.015 \\
(0.065)\end{array}$ & $\begin{array}{c}4.356 * * * \\
(0.878)\end{array}$ & $\begin{array}{c}2.613 * * \\
(1.078)\end{array}$ \\
\hline Secondary industry, $t-1$ & $\begin{array}{c}- \\
0.134 * * * \\
(0.046)\end{array}$ & $\begin{array}{l}-0.061 \\
(0.051)\end{array}$ & $\begin{array}{c}-0.008 * * * \\
(0.002)\end{array}$ & $\begin{array}{c}- \\
0.006 * * * \\
(0.002)\end{array}$ & $\begin{array}{c}-0.184 * * * \\
(0.040)\end{array}$ & $\begin{array}{c}- \\
0.130^{* * * *} \\
(0.042)\end{array}$ \\
\hline Openness, $t-1$ & $\begin{array}{c}- \\
0.061 * * * \\
(0.011)\end{array}$ & $\begin{array}{c}- \\
0.071^{* * *} \\
(0.012)\end{array}$ & $\begin{array}{c}-0.001 * * * \\
(0.000)\end{array}$ & $\begin{array}{c}- \\
0.001 * * * \\
(0.000)\end{array}$ & $\begin{array}{c}0.003 \\
(0.010)\end{array}$ & $\begin{array}{c}0.007 \\
(0.011)\end{array}$ \\
\hline Urbanization, $t-1$ & $\begin{array}{l}0.075 \\
(0.065)\end{array}$ & $\begin{array}{l}-0.118 \\
(0.078)\end{array}$ & $\begin{array}{c}0.020^{* * * *} \\
(0.003)\end{array}$ & $\begin{array}{c}0.010^{* * * *} \\
(0.004)\end{array}$ & $\begin{array}{l}-0.014 \\
(0.055)\end{array}$ & $\begin{array}{c}-0.139 * * \\
(0.063)\end{array}$ \\
\hline Young population, $t-1$ & $\begin{array}{c}0.190 * * \\
(0.095)\end{array}$ & $\begin{array}{c}0.313 * * * \\
(0.099)\end{array}$ & $\begin{array}{c}0.003 \\
(0.007)\end{array}$ & $\begin{array}{c}0.009 \\
(0.007) \\
-\end{array}$ & $\begin{array}{c}0.043 \\
(0.088)\end{array}$ & $\begin{array}{c}0.061 \\
(0.091)\end{array}$ \\
\hline Elderly population, $t-1$ & $\begin{array}{l}-0.094 \\
(0.227)\end{array}$ & $\begin{array}{l}-0.267 \\
(0.234)\end{array}$ & $\begin{array}{c}-0.016 * * \\
(0.008)\end{array}$ & $\begin{array}{l}0.029 * * * \\
(0.008)\end{array}$ & $\begin{array}{c}0.049 \\
(0.191) \\
4.356 * * *\end{array}$ & $\begin{array}{l}-0.036 \\
(0.193) \\
2.613 * *\end{array}$ \\
\hline Country Fixed Effect & Yes & Yes & Yes & Yes & Yes & Yes \\
\hline Year Fixed Effect & No & Yes & No & Yes & No & Yes \\
\hline Observations & 1,201 & 1,201 & 647 & 647 & 1,155 & 1,155 \\
\hline R-squared & 0.083 & 0.144 & 0.114 & 0.172 & 0.105 & 0.196 \\
\hline
\end{tabular}

Note: The dependent variable in Columns (1), (2), (5) and (6) is the primary measure of government size, while the dependent variable in Columns (3) and (4) is the alternative measure of government size. Standard error in parentheses; $* * * \mathrm{p}<0.01, * * \mathrm{p}<0.05, * \mathrm{p}<0.1$. 
Table 4. Robustness Checks: Alternative Data Structure

\begin{tabular}{|c|c|c|c|c|}
\hline & \multicolumn{2}{|c|}{ 5-year Intervals } & \multicolumn{2}{|c|}{ 10-year Intervals } \\
\hline & $(1)$ & $(2)$ & (3) & (4) \\
\hline \multirow[t]{2}{*}{ Expenditure decentralization, $t-1$} & $-0.217 * * *$ & $-0.231 * * *$ & -0.151 & $-0.223^{*}$ \\
\hline & $(0.079)$ & $(0.088)$ & $(0.104)$ & $(0.116)$ \\
\hline \multirow{2}{*}{$\begin{array}{l}\text { Expenditure decentralization } \\
\text { *Democracy } 1, t-1\end{array}$} & $0.028 * *$ & $0.029 * *$ & $0.029 *$ & $0.037 * *$ \\
\hline & $(0.012)$ & $(0.013)$ & $(0.016)$ & $(0.018)$ \\
\hline \multirow{2}{*}{ Democracy $1, t-1$} & $-0.886 * *$ & $-0.881 * *$ & -0.434 & -0.346 \\
\hline & $(0.372)$ & $(0.387)$ & $(0.476)$ & $(0.490)$ \\
\hline \multirow[t]{2}{*}{ GDP per capita, $t-1$} & $6.536 * * *$ & $6.789 * *$ & 2.363 & 4.730 \\
\hline & $(2.484)$ & $(3.215)$ & (3.713) & $(5.041)$ \\
\hline \multirow[t]{2}{*}{ Secondary industry, $t-1$} & $-0.192^{*}$ & $-0.205^{*}$ & -0.068 & -0.141 \\
\hline & $(0.099)$ & $(0.108)$ & $(0.148)$ & $(0.173)$ \\
\hline \multirow[t]{2}{*}{ Openness, $t-1$} & -0.022 & -0.024 & 0.030 & 0.020 \\
\hline & $(0.029)$ & $(0.031)$ & $(0.036)$ & $(0.039)$ \\
\hline \multirow[t]{2}{*}{ Urbanization, $t-1$} & -0.156 & -0.105 & -0.038 & -0.000 \\
\hline & $(0.130)$ & $(0.161)$ & $(0.148)$ & $(0.181)$ \\
\hline \multirow[t]{2}{*}{ Young population, $t-1$} & -0.074 & -0.035 & 0.064 & 0.266 \\
\hline & $(0.220)$ & $(0.245)$ & $(0.285)$ & $(0.321)$ \\
\hline \multirow[t]{2}{*}{ Elderly population, $t-1$} & 0.047 & -0.031 & 0.497 & 0.301 \\
\hline & $(0.529)$ & $(0.550)$ & $(0.574)$ & $(0.603)$ \\
\hline Country Fixed Effect & Yes & Yes & Yes & Yes \\
\hline Year Fixed Effect & No & Yes & No & Yes \\
\hline Observations & 245 & 245 & 245 & 245 \\
\hline R-squared & 0.113 & 0.125 & 0.154 & 0.164 \\
\hline
\end{tabular}

Note: The dependent variable is the primary measure of government size. In the estimations of Columns (1) and (2), we transform the yearly data into 5-year intervals (i.e., 1972-1974; 1975-1979;..; 2005 2009; 2010-2013); in the estimations of Columns (3) and (4), we transform the yearly data into 10-year intervals (i.e., 1972-1979; 1980-1989; 1990-1999; 2000-2009; 2010-2013). Standard error in parentheses; $* * * \mathrm{p}<0.01, * * \mathrm{p}<0.05, * \mathrm{p}<0.1$. 
Table 5. Robustness Checks: IV Estimations

\begin{tabular}{lcccc}
\hline & $(1)$ & $(2)$ & $(3)$ & $(4)$ \\
\hline Expenditure decentralization, $t-1$ & $-0.598^{* * *}$ & $-0.663^{* * *}$ & $-1.132^{* *}$ & $-1.374^{* * *}$ \\
& $(0.179)$ & $(0.187)$ & $(0.460)$ & $(0.463)$ \\
Expenditure decentralization & & & $0.094^{*}$ & $0.119^{* *}$ \\
*Democracy 1, $t-1$ & & & $(0.049)$ & $(0.049)$ \\
Democracy 1, $t-1$ & & & $-1.581^{* *}$ & $-1.679^{* *}$ \\
& & & $(0.717)$ & $(0.720)$ \\
GDP per capita, $t-1$ & 0.492 & $-6.586^{* * *}$ & -0.883 & $-6.401^{* * *}$ \\
& $(1.146)$ & $(1.718)$ & $(1.237)$ & $(1.520)$ \\
Secondary industry, $t-1$ & $-0.410^{* * *}$ & $-0.240^{* * *}$ & $-0.403^{* * *}$ & $-0.272^{* * *}$ \\
& $(0.061)$ & $(0.055)$ & $(0.057)$ & $(0.057)$ \\
Openness, $t-1$ & 0.0004 & -0.002 & -0.003 & 0.008 \\
& $(0.013)$ & $(0.011)$ & $(0.011)$ & $(0.011)$ \\
Urbanization, $t-1$ & -0.046 & $-0.385^{* * *}$ & -0.018 & $-0.288^{* * *}$ \\
& $(0.064)$ & $(0.086)$ & $(0.058)$ & $(0.064)$ \\
Young population, $t-1$ & $-0.376^{* * *}$ & $-0.323^{* *}$ & $-0.516^{* * *}$ & $-0.518^{* * *}$ \\
& $(0.146)$ & $(0.154)$ & $(0.110)$ & $(0.108)$ \\
Elderly population, $t-1$ & 0.398 & 0.181 & 0.173 & -0.009 \\
& $(0.244)$ & $(0.223)$ & $(0.191)$ & $(0.189)$ \\
Country Fixed Effect & & & & \\
Year Fixed Effect & Yes & Yes & Yes & Yes \\
Observations & No & Yes & No & Yes \\
R-squared & 926 & 926 & 918 & 918 \\
IV F-stat & 0.068 & 0.138 & 0.214 & 0.309 \\
Sargan P-values & 9.59 & 8.48 & 23.57 & 20.44 \\
\hline
\end{tabular}

Note: The dependent variable is the primary measure of government size. The instruments are oneperiod and two-period lagged values of the weighted average of fiscal decentralization from the neighboring countries (weighed by the contiguity matrix). Standard error in parentheses; $* * * \mathrm{p}<0.01$, ** $\mathrm{p}<0.05, * \mathrm{p}<0.1$. 


\section{Appendix}

Table A1. The List of Countries used in the Sample

\begin{tabular}{|c|c|c|c|c|c|c|c|}
\hline 1 & Albania & 21 & Czech Republic & 41 & Jamaica & 61 & Peru \\
\hline 2 & Argentina & 22 & Germany & 42 & Jordan & 62 & Poland \\
\hline 3 & Armenia & 23 & Denmark & 43 & Japan & 63 & Portugal \\
\hline 4 & Australia & 24 & Dominican Republic & 44 & Kazakhstan & 64 & Paraguay \\
\hline 5 & Austria & 25 & Spain & 45 & Korea, Rep. & 65 & Russian Federation \\
\hline 6 & Azerbaijan & 26 & Estonia & 46 & Lesotho & 66 & El Salvador \\
\hline 7 & Belgium & 27 & Finland & 47 & Lithuania & 67 & Serbia \\
\hline 8 & Bulgaria & 28 & France & 48 & Luxembourg & 68 & Slovak Republic \\
\hline 9 & Bosnia and Herzegovina & 29 & United Kingdom & 49 & Latvia & 69 & Slovenia \\
\hline 10 & Belarus & 30 & Georgia & 50 & Morocco & 70 & Sweden \\
\hline 11 & Bolivia & 31 & Greece & 51 & Moldova & 71 & Thailand \\
\hline 12 & Brazil & 32 & Honduras & 52 & Mexico & 72 & Tunisia \\
\hline 13 & Canada & 33 & Croatia & 53 & Macedonia, FYR & 73 & Turkey \\
\hline 14 & Switzerland & 34 & Hungary & 54 & Malta & 74 & Ukraine \\
\hline 15 & Chile & 35 & India & 55 & Mongolia & 75 & United States \\
\hline 16 & Congo, Rep. & 36 & Ireland & 56 & Mauritius & 76 & South Africa \\
\hline 17 & Colombia & 37 & Iran, Islamic Rep. & 57 & Malaysia & & \\
\hline 18 & Cabo Verde & 38 & Iceland & 58 & Netherlands & & \\
\hline 19 & Costa Rica & 39 & Israel & 59 & Norway & & \\
\hline 20 & Cyprus & 40 & Italy & 60 & New Zealand & & \\
\hline
\end{tabular}


Table A2. Description of Variables and Sources

\begin{tabular}{|c|c|c|}
\hline Variable & Definition & Source \\
\hline Government size, primary & $\begin{array}{l}\text { Share of total government expenditure } \\
\text { to GDP, } \%\end{array}$ & $\begin{array}{l}\text { World } \\
\text { Development } \\
\text { Indicators (WDI) } \\
\text { database }\end{array}$ \\
\hline $\begin{array}{l}\text { Government size, } \\
\text { alternative }\end{array}$ & Total public sector employment, log & $\begin{array}{l}\text { The International } \\
\text { Labor Organization } \\
\text { database }\end{array}$ \\
\hline $\begin{array}{l}\text { Expenditure } \\
\text { decentralization }\end{array}$ & $\begin{array}{l}\text { Ratio of subnational government } \\
\text { expenditure to the total general } \\
\text { government expenditure, \% }\end{array}$ & $\begin{array}{l}\text { World Bank's } \\
\text { Decentralization } \\
\text { Indicator database }\end{array}$ \\
\hline Revenue decentralization & $\begin{array}{l}\text { Ratio of subnational government } \\
\text { revenue to the total general } \\
\text { government revenue, } \%\end{array}$ & $\begin{array}{l}\text { World Bank's } \\
\text { Decentralization } \\
\text { Indicator database }\end{array}$ \\
\hline Democracy 1 & $\begin{array}{l}\text { Average of political right index and } \\
\text { civil liberties index. It is rescaled to } \\
\text { take values between } 0 \text { and } 10 \text {, with the } \\
\text { larger value signifying a more } \\
\text { democratic regime }\end{array}$ & Freedom House \\
\hline Democracy 2 & $\begin{array}{l}\text { The index of political democracy } \\
\text { and autocracy }\end{array}$ & $\begin{array}{l}\text { The Polity IV } \\
\text { Project dataset }\end{array}$ \\
\hline GDP per capita, log & $\begin{array}{l}\text { Real GDP per capita ( } 1985 \text { fixed } \\
\text { price), log }\end{array}$ & WDI \\
\hline Secondary industry & $\begin{array}{l}\text { Share of secondary sector in total } \\
\text { GDP, \% }\end{array}$ & WDI \\
\hline Openness & $\begin{array}{l}\text { Ratio of total trade (exports and } \\
\text { imports) to GDP, } \%\end{array}$ & WDI \\
\hline Urban & $\begin{array}{l}\text { Share of urban population in the total } \\
\text { population, } \%\end{array}$ & WDI \\
\hline Young population & $\begin{array}{l}\text { Share of young population (ages } 0-14 \text { ) } \\
\text { in total population, } \%\end{array}$ & WDI \\
\hline Elderly population & $\begin{array}{l}\text { Share of young population (ages } 65 \\
\text { and above) in total population, } \%\end{array}$ & WDI \\
\hline $\begin{array}{l}\text { IV: Weighted fiscal } \\
\text { decentralization }\end{array}$ & $\begin{array}{l}\text { The weighted average of fiscal } \\
\text { decentralization from the neighboring } \\
\text { countries (weighted by the contiguity } \\
\text { matrix) }\end{array}$ & $\begin{array}{l}\text { Authors' } \\
\text { calculations }\end{array}$ \\
\hline
\end{tabular}

